\title{
COMPOSITE GFRP U-SHAPED FOOTBRIDGE
}

\author{
Jacek Chróścielewski \\ Mikołaj Miśkiewicz \\ Lukasz Pyrzowski \\ Krzysztof Wilde \\ Gdansk University of Technology, Poland
}

\begin{abstract}
The paper presents proposals for the use of glass fiber reinforced polymer composites for the construction of engineering objects, known and commonly used in the shipbuilding industry. An example of a pedestrian footbridge was used in this case, which, despite the considerable thickness of the structural material, was made using infusion technology in one production cycle. The designed and produced footbridge span is durable, dynamically resistant, incombustible, easy to install and maintain, resistant to weather conditions and also aesthetically interesting. For footbridge production environmentally friendly PET foam core may be used. It may come from recycling of used plastic packages and which is produced with less energy consumption process and much less $\mathrm{CO} 2$ emission. The load bearing part of the structure (skin) is made of polymer laminate reinforced with glass fabrics (GFRP).
\end{abstract}

Keywords: polymer composites, sandwich structures, footbridge, fobridge

\section{INTRODUCTION}

Polymer composites are structures consisting of two or more components. The primary element is reinforcement, which affects the strength and rigidity of the composite element. In the composite constructions of the shipbuilding industry and in the land transport infrastructure, the reinforcement is usually made of glass, carbon, or aramid fibers. The second essential component of the composite is the matrix, which provides the shape, the appropriate distribution of reinforcement, and the distribution of load along the composite volume. The shell material may be, for example, a polyester, vinyl ester or epoxy resin. Composite structures are often combined into so-called sandwich structures, which additionally employ a lightweight filler core to maintain the distance of the outer bearing skins. The most important advantages of this material are: low volume weight, relatively high rigidity and strength, high resistance to atmospheric [14] and chemical factors, and great flexibility in geometrical shaping.

All of the above factors cause the share of polymer composites in various industries to grow year by year. This is particularly evident in the shipbuilding industry, where they have been used from the very onset of their invention. Composites now find use in the production of small craft as well as ships or parts thereof [22]. One example is the modern ferry, Vision of The Fjords (see Fig. 1), launched in 2016.

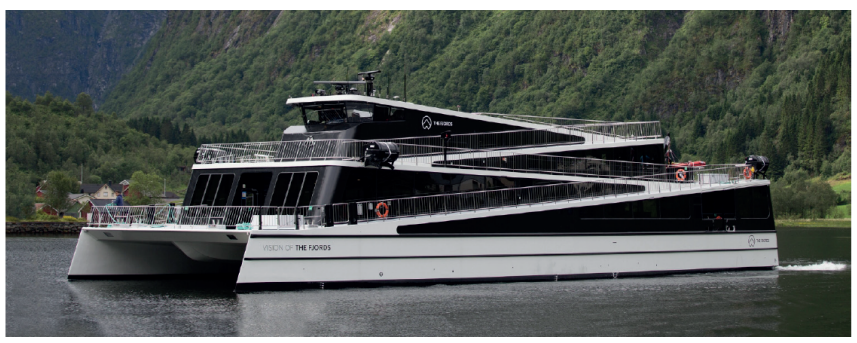

Fig. 1. The passenger ferry „Vision of The Fjords” [www.braa.no]

Currently, several technologies of composite construction are in use. The most popular are hand layup, pultrusion, and vacuum infusion. In shipbuilding applications, due to dominating production of surface elements, infusion is primarily used. This technology is based on manufacture of composite structures by placing dry reinforcement in mold, 
on a pre-applied gel coat. Next, a delamination fabric and a mesh to improve the flow of the resin are put into place, and the whole assembly is sealed in a vacuum-sealed bag. The final step is to create a vacuum to distribute the resin, which must uniformly infuse the reinforcement. Infusion technology has many advantages: it provides great elasticity in forming, reduces the volatilization of chemicals in the production process, the components are characterized by a high degree of reinforcement and can be used for sandwich structures. An example production photo is shown in Fig. 2.

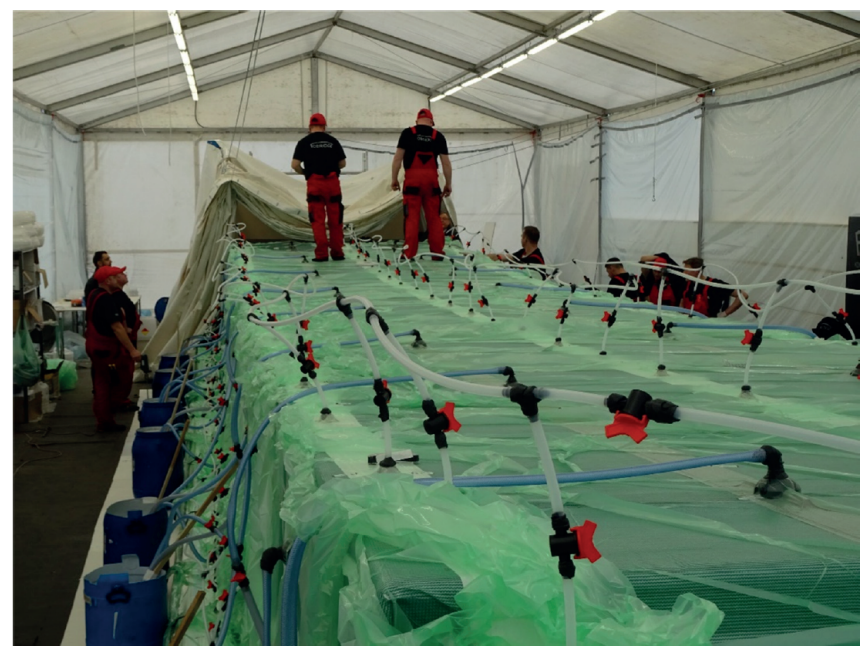

Fig. 2. Preparation to infusion of a large-size object - footbridge span of Fobridge grant

The advantages of polymer composites make them likely to be used not only in shipbuilding or aviation, but also in land transport infrastructure. The specific application is bridge-building [6], [7], [10], [26]. In recent years, a growing number of engineering designs have been developed that utilize this material in whole or in part. An example of a composite structure is the Ubridge pedestrian-cyclist bridge, which was created within the framework of the FOBRIDGE project, realized by the consortium of the Gdańsk University of Technology, the Military Academy of Technology in Warsaw, and Roma Ltd. in 2015 [6],[20]. One of the goals of the project was to make a footbridge competitive in terms of price with traditional steel, concrete, or wood bridges. To achieve this, both the material (glass reinforced composite sandwich-construction based on vinyl ester resin) and the production technology (infusion) used in other applications, such as shipbuilding, were applied. The FOBRIDGE project assumes that the bridge span will be a freely supported and constructed as U-shaped cross-section girder (Fig. 3) made of a three-ply sandwich shell with laminated, glass fiber reinforced skins, separated by a thick PET foam core. This example of the use of composite materials in construction will be described in detail in this paper.

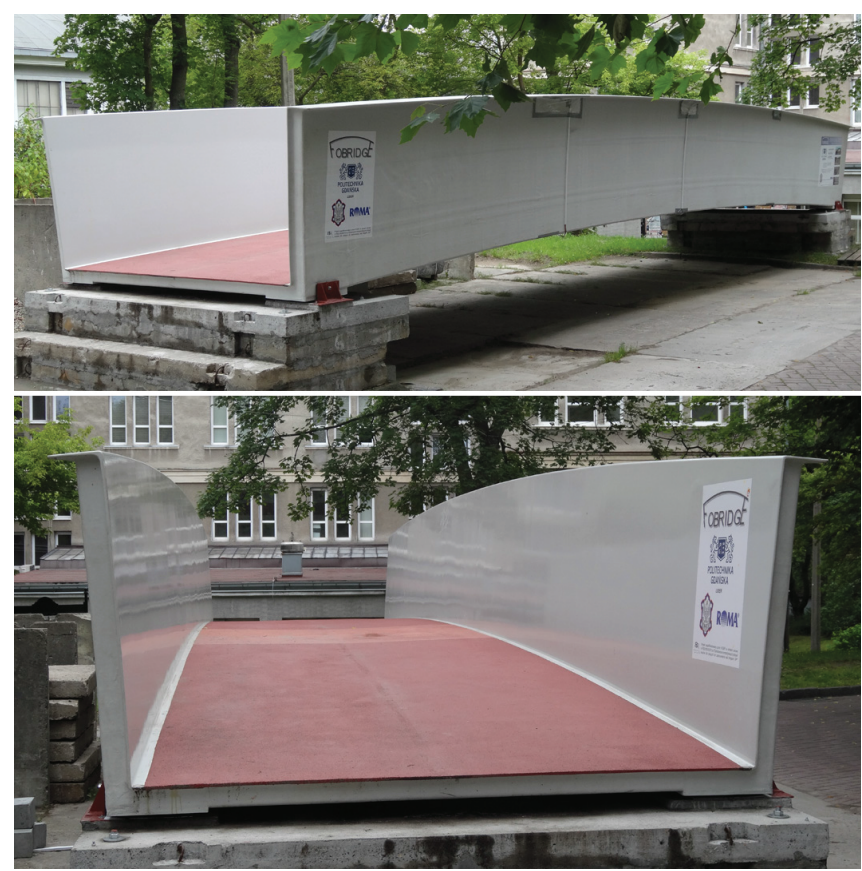

Fig. 3. Composite span of the FOBRIDGE walking and cycling bridge

The characteristics of the composite material, especially its low weight, offer designers much freedom. This is especially apparent in drawbridge construction. The use of lightweight platforms offers the possibility of designing more slender girders and mechanisms for lifting or rotating the spans [18], [25]. One example of polymer composites used in a drawbridge is the Dragon's Bridge in Rhyl, Wales, put to use in 2013 (Fig. 4).

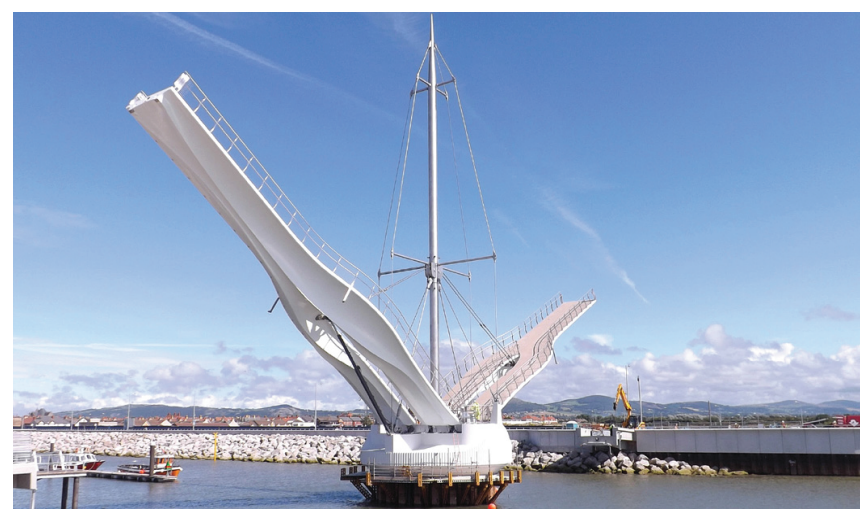

Fig. 4. The drawbridge Dragon's Bridge in the port of Rhyl in Wales [www. gurit.com]

\section{ARCHITECTURAL CONCEPTS AND DESIGN DESCRIPTION}

Various forms of construction, with the assumed theoretical single span in the range of 12 to $18 \mathrm{~m}$ were considered in the architectural conceptual work. Selected architectural variants 

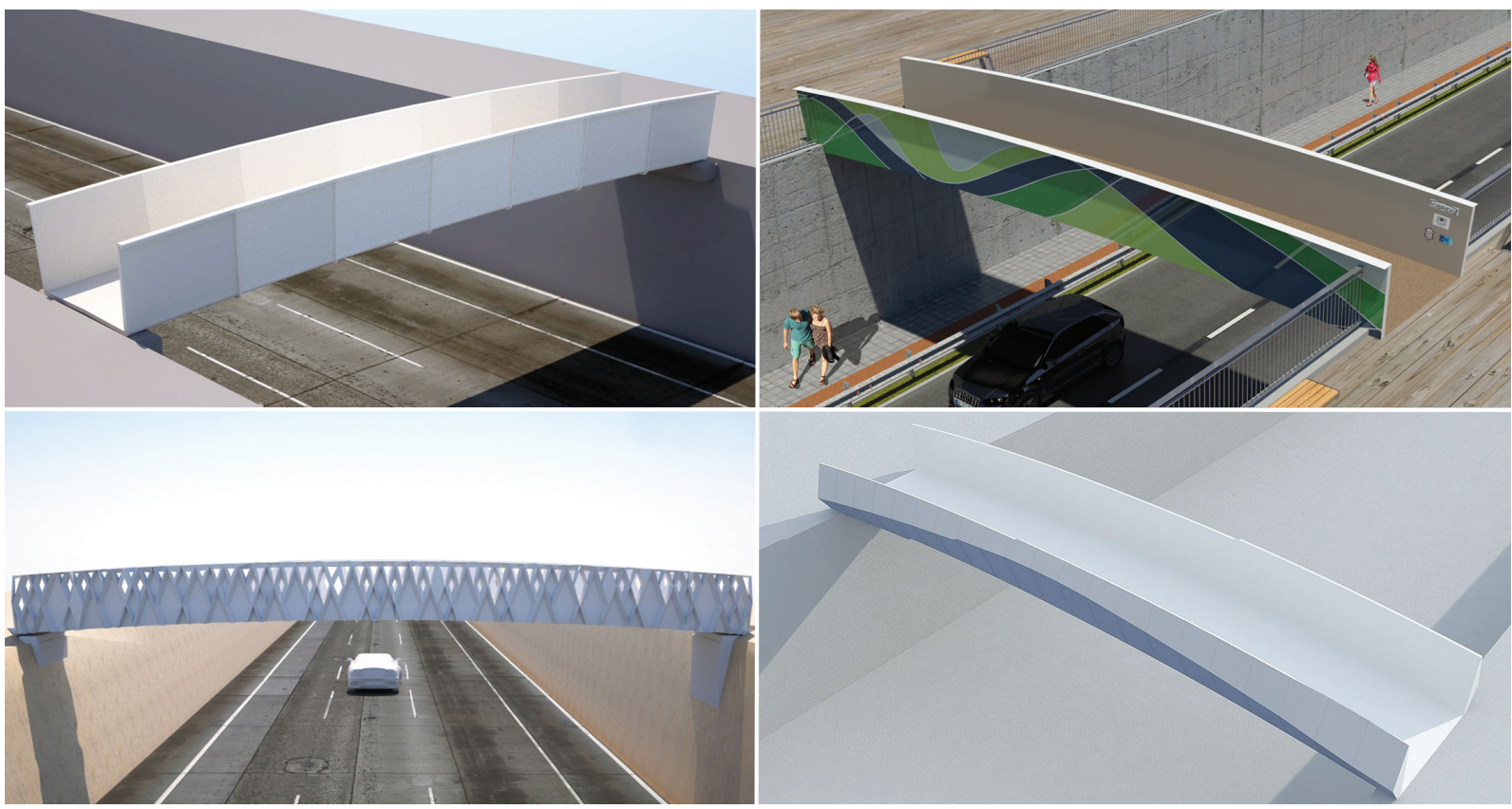

Fig. 5. Architectural concepts of composite footbridge: color, light and texture [6], [7]

of the footbridge, using color, light and texture, are presented in Fig. 5.

The footbridge is designed to facilitate pedestrian and bicycle traffic over obstacles as well as to incidentally allow an ambulance or service vehicle to pass. The resulting structural design of the span, its lightness, and hence its small support requirements make it perfect for use over any obstacle (road, railway, waterway, off-shore platforms, etc.). Due to these features and the short production time, the proposed spans can be particularly useful in disaster areas, where immediate reconstruction of destroyed communication routes with minimum technical requirements is vitally important. In addition, using the $\mathrm{U}$-shape structural design, sandwich components were incorporated into the structural work of the system, hence the object has a very small construction height of only a dozen or so centimeters. The side walls of the U-shape are also handrails, with a height of $1.3 \mathrm{~m}$. The axial geometry of the support construction is described by a circular arc, and the maximum longitudinal drop does not exceed $8 \%$ (Fig. 6).

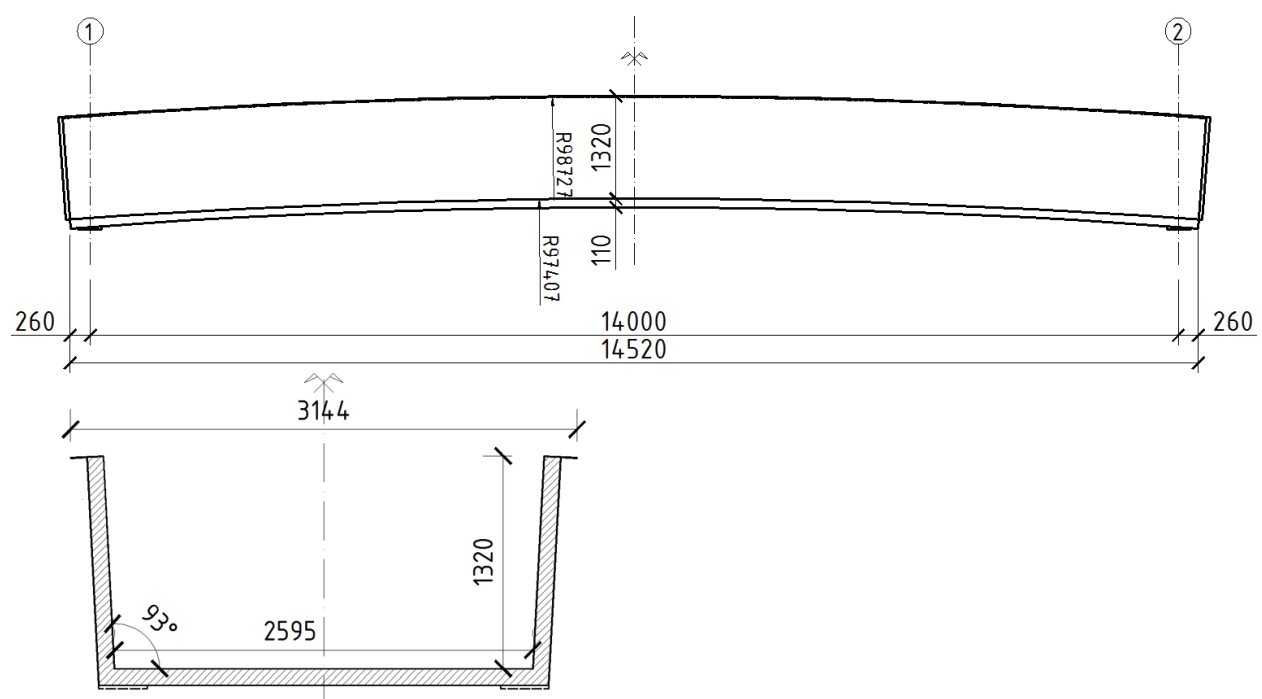

Fig. 6. Side view and cross-section of the span 
The span was produced entirely with infusion technology, in one technological cycle, and the produced full-scale footbridge corresponds to the architectural vision (Fig. 7).

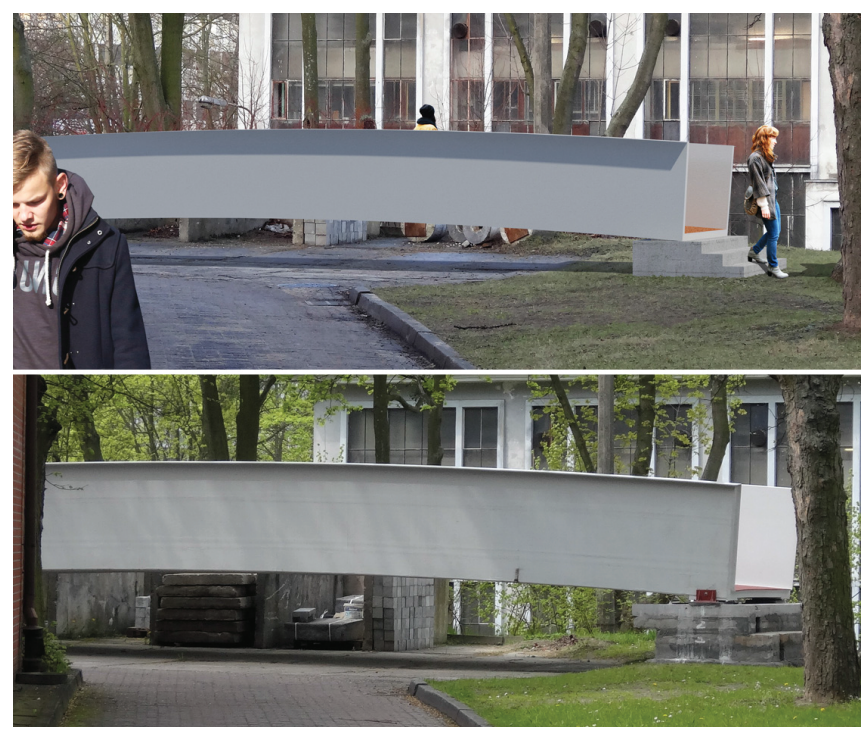

Fig. 7. FOBRIDGE span: top - architectural vision, bottom - finished product

\section{IDENTIFICATION AND VALIDATION STUDIES}

The process of designing and manufacturing an innovative composite bridge required solving various problems. The most important were: absence of standard guidelines for designing composite elements in construction applications, no standardized material data, no guidelines for calculating and evaluating material strain, and no guidelines for bulk infusions and resulting thick spacers. Finding the answers required a number of experimental, validation, and numerical studies and many technological trials related to the selection of material parameters and control of the infusion process.

Experimental studies performed included:

- identification of mechanical parameters of materials analogous to [1], [2];

- $\quad$ static and dynamic testing of samples in the technical scale of the finished sandwich [23];

- structural and local tests with acoustic emission measurements [12], of a 3-meter segment with target cross section [8],[19] (Fig. 9);

- load-carrying test of full-size object [9].

In this latter study group, long-term technical monitoring of the bridge span [21] was performed. Among other things, the purpose of experimental research was to obtain data for the formulation and validation of analytical and numerical computing models of laminate, foam, sandwich, and structural work of the entire system.

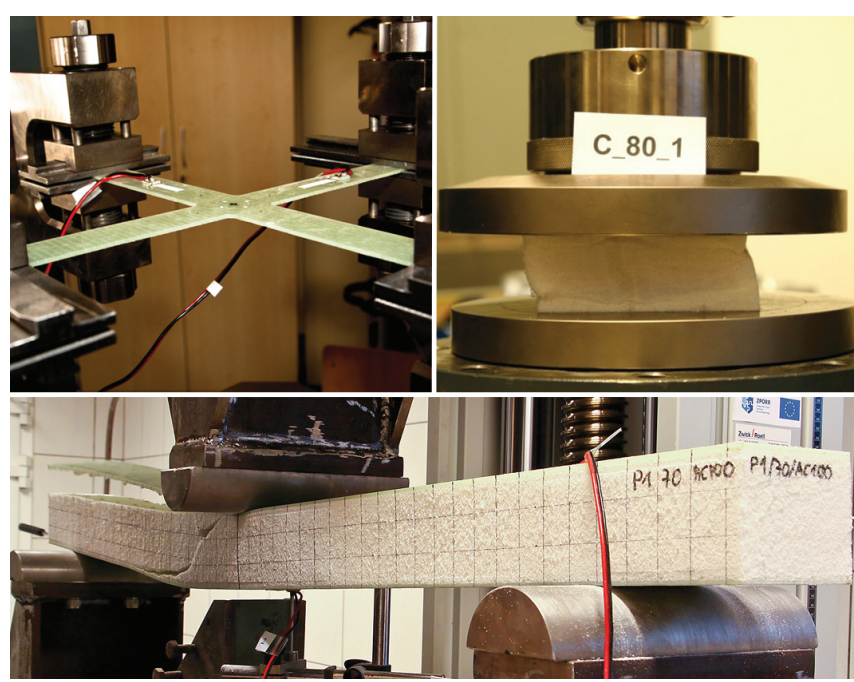

Fig. 8. Selected material identification studies: laminate and foam and validation of the sandwich structure calculation model [8], [10]

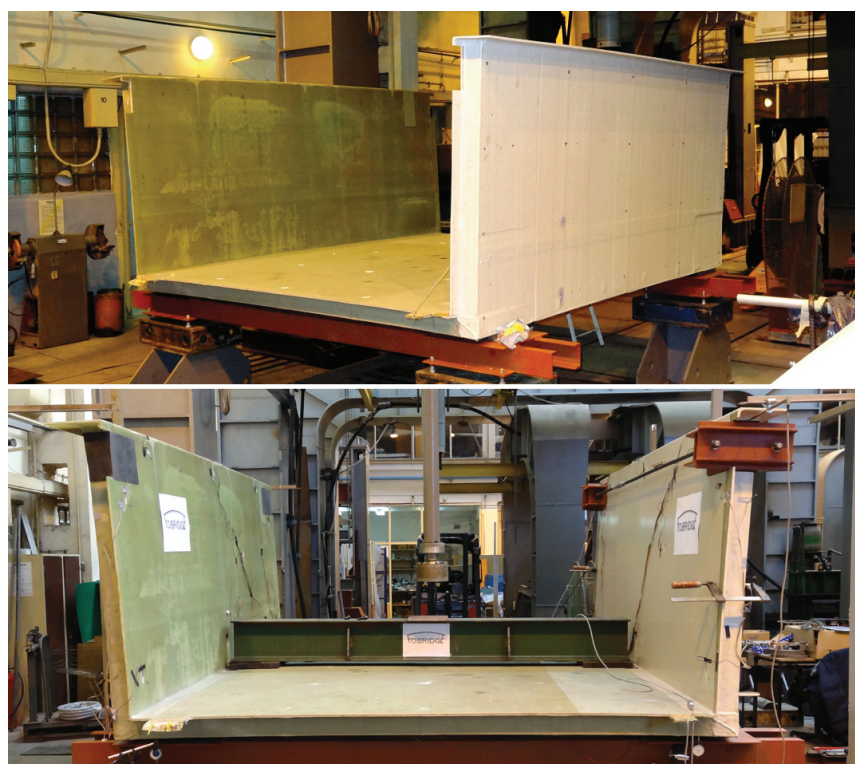

Fig. 9. Three-meter long validation footbridge segment with target cross-section

For numerical investigations the usual solutions of finite element method, highly advanced calculation techniques developed by these authors and commercial FEM tools were used (e.g. [5], [11], [13], [15], [16], [17], [24]. These programs have been tested for their suitability for modeling composite spacer structures. The ROBOT, SOFiSTiK, and more advanced ABAQUS and MSC Marc, NX NASTRAN (Fig. 10) programs were acquired. As a result of these studies, an algorithm and computational model was developed for solving engineering problems with laminates, where high compatibility between simulations and real experiments was achieved. The developed computational model was used to design a full bridge span. 

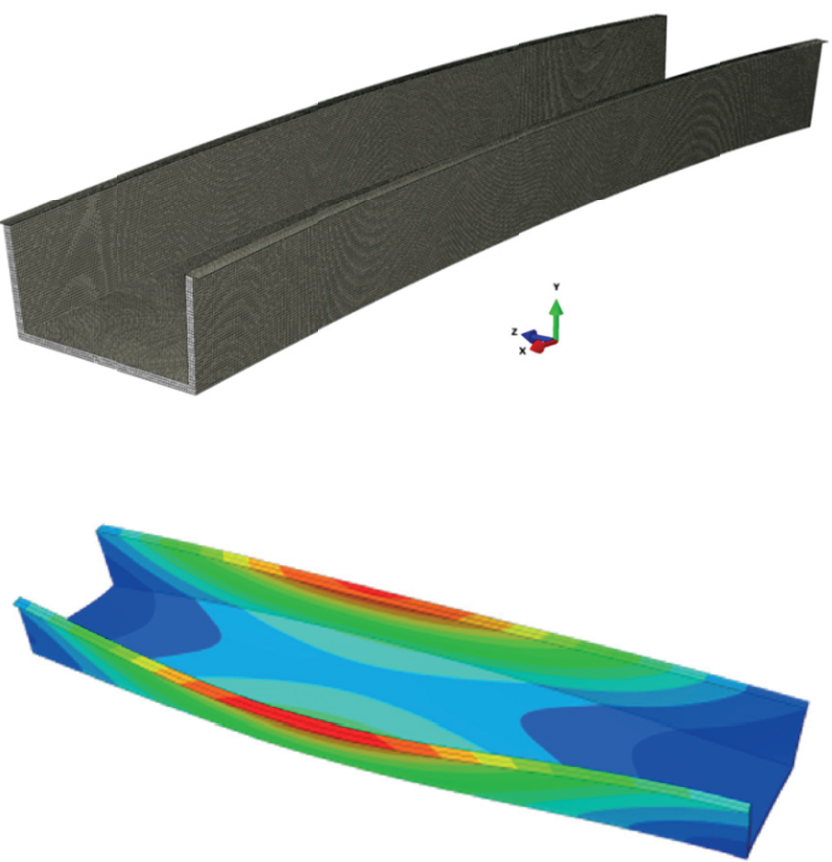

Fig. 10. Visualization of the selected target bridge span model (top) and its $1^{\text {st }}$ form of natural vibration

In the subsequent stages of the study, multiple selection criteria were selected and finally a full-size test object was produced using a vinyl ester resin as the matrix and orthogonally stitched fabrics, quasi-balanced, made of type E fiberglass, as reinforcement of the shell laminate, and perforated PET foam with a density of $100 \mathrm{~kg} / \mathrm{m}^{3}$, forming a $100-\mathrm{mm}$ core of a three-layer sandwich.

\section{INSTALLATION AND ACCEPTANCE TESTS}

The research object of the FOBRIDGE project, in the form of a full bridge span of a total length of $14.5 \mathrm{~m}$, was transported from Grabowiec near Torun to the Gdansk University of Technology by means of standard wheel transport (Fig. 11) and assembled using a small crane (Fig. 12). The total mass of the span was approximately $3.3 \mathrm{t}$.

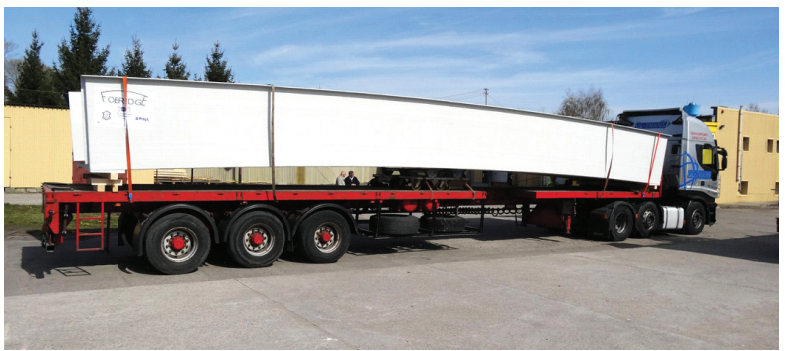

Fig. 11. Transporting the footbridge span

In order to facilitate further research, the span was situated on reinforced concrete road-slabs, simulating low-rise bridgeheads. Ultimately, a special bearing design was used to secure the bridge from breaking off, which can be caused by winds in the case of such lightweight constructions. The span is only $14 \mathrm{~m}$ long, hence the bridge is classified as a small object, as bridges go. Nevertheless, for research purposes, it was decided to monitor a wide range of its parameters. For this reason, a total of 216 different types of measuring points were assumed in the main static and dynamic surveys, including the typical bridge approval load tests. In the basic static test, concrete road slabs were laid in different configurations, with a total weight of $141 \mathrm{kN}$ (Fig. 12) [9]. In addition, a live crowd load of over 100 people was used. Laser scanning was performed on one side of the span [3], [4] and measurement points included: strains (electrical resistance strain gauges, extensometric and fiber optic gauges), displacements (induction sensors, geodetic measurements), bearing distortion, support settlement, and construction temperature measurements. Dynamic tests (Fig. 12) included measurements of strains (electrical resistance strain gauges and fiber optic gauges), displacement (induction sensors), accelerations, and angular velocities.
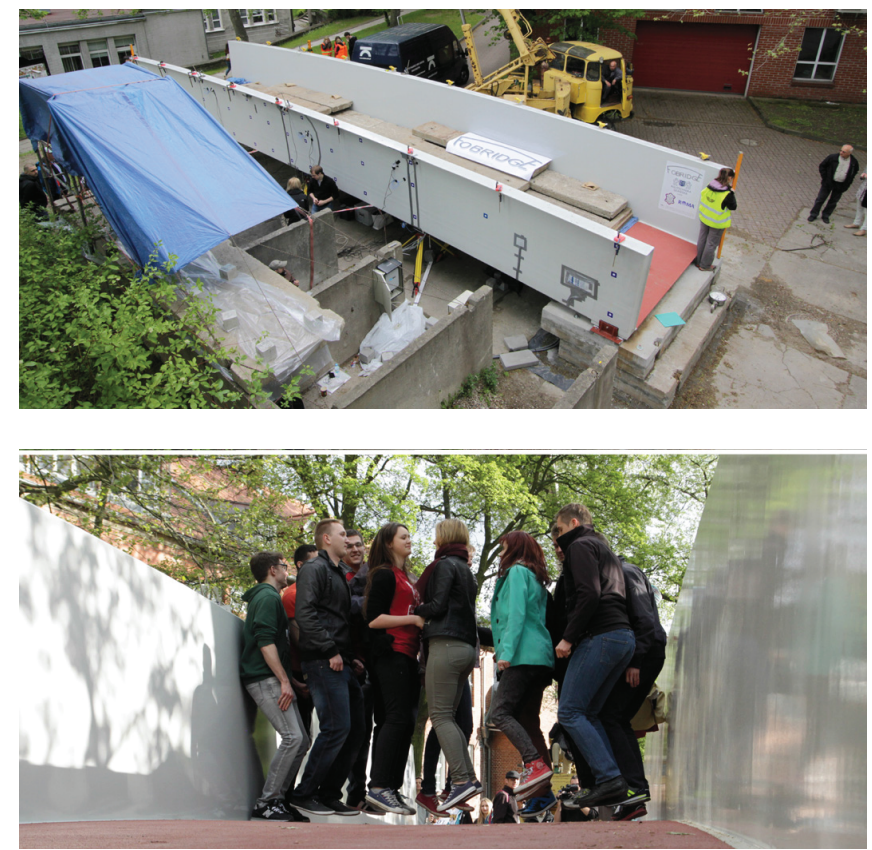

Fig. 12. Example tests: static loading with concrete road slabs (top); dynamic, synchronous jumps by a group of pedestrians (bottom)

\section{SUMMARY}

As a result of the study, a lightweight bridge-type object has been developed and manufactured with many desirable properties: durable, dynamic, flame retardant, easy to assemble and maintain, resistant to atmospheric factors, and, moreover, aesthetic. The sandwich core material is made of environmentally friendly PET foam, which can be produced using significantly less energy-consuming processes than 
those used for producing more traditional materials, with reduced $\mathrm{CO}_{2}$ emissions, and utilizing materials from recycled plastic bottles. A modern construction material, glass fiber reinforced polymer laminate, was used to make the footbridge structure, and the entire girder is one compact piece - without "foreign" parts that could weaken the object and corrode faster. It is assumed that upon termination of the footbridge usability period, the fiberglass and the PET foam core will be recovered and will continue to be used in subsequent constructions. Another advantage is that the process of manufacturing takes only a few days utilizing the standard infusion technology. This process allows us to obtain a highquality product every time with a significantly reduced price from other manufacturing methods. The U-bridge's final price will be comparable to traditional solutions (steel, concrete, wood) already at the time of purchase and, taking into account the 50-year period of usability with zero necessity of maintenance, will ultimately be significantly lower. Due to the low weight of the construction, only lightweight equipment will be required for assembly, and the supports will be small in even the most unfavorable geotechnical conditions. Other properties of note include the low constructional height $(0.14 \mathrm{~m})$ and excellent dynamic parameters of the object (7.8 Hz first frequency of vibration). It is assumed that the target footbridge, even at the prefabrication stage, due to the use of fiberglass as reinforcement, will be able to be equipped with a technical monitoring system based on fiber Bragg grating (FBG) sensors.

\section{BIBLIOGRAPHY}

1. Ambroziak A., Kłosowski P.: Mechanical properties of polyvinyl chloride-coated fabric under cyclic tests. Journal Of Reinforced Plastics And Composites. Vol. 33, No. 3 (2014), pp. 225-234

2. Ambroziak A., Kłosowski P.: Mechanical testing of technical woven fabrics. Journal Of Reinforced Plastics And Composites. Vol. 32, No. 10 (2013), pp. 726-739.

3. Bobkowska K., Janowski A., Przyborski M., Szulwic J.: Analysis of High Resolution Clouds of Points as a Source of Biometric Data. 2016 Baltic Geodetic Congress (BGC Geomatics)/ : IEEE, 2016, pp.15-21

4. Burdziakowski P., Janowski A., Kholodkov A., Matysik K., Matysik M., Przyborski M., Szulwic J., Tysiąc P., Wojtowicz A.: Maritime laser scanning as the source for spatial data. Polish Maritime Research, Vol. 22, No. 4(88) (2015), pp. 9-14.

5. Burzyński S., Chróścielewski J., Witkowski W.: Geometrically nonlinear FEM analysis of 6-parameter resultant shell theory based on 2-D Cosserat constitutive model. ZAMM- Zeitschrift fuer Angewandte Mathematik und Mechanik, Vol. 96, No. 2 (2015), pp.191-204
6. Chróścielewski J., Klasztorny M., Miśkiewicz M., Romanowski R., Wilde K.: Innovative design of GFRP sandwich footbridge, Proc. $5^{\text {th }}$ International Conference on Footbridges: Past, Present \& Future, Footbridge 2014, London, England, 16-18 July 2014, Paper \#1250, pp. 1-8

7. Chróścielewski J., Klasztorny M., Wilde K., Miśkiewicz M., Romanowski R.: Composite sandwich bridge for pedestrians and bicyclists ( in Polish), Materiały Budowlane 7/2014 (No. 503), pp. 1-2.

8. Chróścielewski J., Miśkiewicz M., Pyrzowski Ł., Rucka M, Ferenc T.: Experimental tests of a validation segment of composite foot - bicycle bridge (in Polish). Materiały Budowlane 4/2015 (No. 512), pp. 72-73.

9. Chróścielewski J., Miśkiewicz M., Pyrzowski Ł., Wilde K.: Tests of a composite footbridge ( in Polish). Mosty, 1/2016, pp. 44-49.

10. Chróścielewski J., Miśkiewicz M., Wilde K. A composite foot - bicycle bridge. ( in Polish). II Konferencja NaukowoTechniczna Współczesne Materiały, Techniki i Technologie we Współczesnym Budownictwie ( $2^{\text {nd }}$ Scientifical Technical Conference on Contemporary Materials, Techniques and Technologies in Today Building Industry), Cracow, $21 \div 23$ -10-2015, pp. 67-74

11. Chróścielewski J., Witkowski W.: Four-node semi-EAS element in six-field nonlinear theory of shells. International Journal for Numerical Methods In Engineering 68(11), 2006, pp. 1137-1179.

12. Grelowska G., Kozaczka E., Nowicki A., Kozaczka S.: Investigation of Transmit and Receive Characteristics of Laboratory Model for the Parametric Echosounder. Acta Physica Polonica A., Vol. 123, No. 6 (2013), pp.1094-1097

13. Iwicki P., Tejchman A., Chróścielewski J.: Dynamic FE simulations of buckling process in thin-walled cylindrical metal silos. Thin-Walled Structures. Vol. 84 (2014), pp.344-359.

14. Jakubowski M.: Influence of pitting corrosion on fatigue and corrosion fatigue of ship and offshore structures. Part II: Load - pit crack interaction. Polish Maritime Research. -Vol. 22, No. 3 (2015), pp. 57-66.

15. Klasztorny M., Bondyra, A., Szurgott, P., Nycz, D.: Numerical modelling of GFRP laminates with MSC. Marc system and experimental validation. Computational Materials Science, vol. 64, 2012, pp. 151-156. DOI: 10.1016/j. commatsci.2012.05.024

16. Kaliński K.: The finite element method application to linear closed loop steady system vibration analysis. International Journal of Mechanical Sciences 39 (3), 1997, pp. 315-330. 
17. Łuczak M., Manzato S., Peeters B., Branner K., Berring P., Kahsin M.: Updating Finite Element Model of a Wind Turbine Blade Section Using Experimental Modal Analysis Results. Shock And Vibration, No. 1 (2014), pp. 71-82.

18. Mikielewicz J., Mikielewicz D. : A simple model of circular hydraulic pump. International Journal of Heat and Mass Transfer, Vol. 52(1), (2008) pp.17-21,.

19. Miśkiewicz M, Daszkiewicz K., Ferenc T. Witkowski W and Chróścielewski J.: Experimental tests and numerical simulations of full scale composite sandwich segment of a foot-and-cycle bridge. Advances in Mechanics: Theoretical, Computational and Interdisciplinary Issues - Kleiber et al. (Eds), Taylor \& Francis Group, London, 2016, pp. 401-404.

20. Miśkiewicz M., Okraszewska R., Pyrzowski Ł. : Composite footbridge-synergy effect in cooperation between universities and industry. ICERI2014: $7^{\text {th }}$ International Conference of Education, Research and Innovation, ICERI Proceedings, (2014), pp. 2897-2903.

21. Miśkiewicz M., Pyrzowski Ł., Chróścielewski J., Wilde K.: Structural Health Monitoring of Composite Shell Footbridge for Its Design Validation. Proceedings 2016 Baltic Geodetic Congress (Geomatics)/ ed. Juan E. Guerrero Los Alamitos: IEEE Computer Society Order Number E5972, 2016, pp. 228-233.

22. Niklas K., Kozak J.: Experimental investigation of SteelConcrete-Polymer composite barrier for the ship internal tank construction. Ocean Engineering. Vol. 111, (2016), pp. 449-460.

23. Pyrzowski Ł., Sobczyk B., Witkowski W., Chróścielewski J.: Three-point bending test of sandwich beams supporting the GFRP footbridge design process validation. $3^{\text {rd }}$ Polish Congress of Mechanics (PCM) / 21st International Conference on Computer Methods in Mechanics (CMM), 2016, Taylor \& Francis Group, London, pp. 489-492.

24. Sabik A., Kreja I.: Large thermo-elastic displacement and stability FEM analysis of multilayered plates and shells. Thin-Walled Structures 71, (2013), pp.119-133.

25. Siemiątkowski M., Przybylski W. : Simulation studies of process flow with in-line part inspection in machining cells. Journal of Materials Processing Technology Volume 171, No. 1, January 10, 2006, pp. 27-34.

26. Siwowski T., Kulpa M., Poneta P.: Research on application of FRP composites to bridge building in Poland (in Polish). Materiały Budowlane 11/2014

\section{CONTACT WITH THE AUTHOR}

Jacek Chróścielewski

Mikołaj Miśkiewicz

Łukasz Pyrzowski

Krzysztof Wilde

Gdańsk University of Technology

Faculty of Civil Engineering and Environment 11/12 Narutowicza St. 80 - 233 Gdańsk

Poland 